\title{
Calcareous nannofossils from the middle/upper Miocene succession of Pécs-Danitzpuszta, southern Hungary: cosmopolitan Paratethys and endemic Lake Pannon assemblages
}

\author{
ĆORIĆ, Stjepan \\ Geological Survey of Austria, 1030 Vienna, Neulinggasse 38., stjepan.coric@ geologie.ac.at \\ ORCID: 0000-0001-6242-8473
}

\section{Mészvázú nannofosszíliák Pécs-Danitzpuszta középsölfelsố miocén képződményeiböl}

Összefoglalás

A pécs-danitzpusztai homokbányában feltárt középső és késő miocén (szarmata és pannóniai) rétegsor 109 mintáján végeztük el mészvázú nannofosszíliák mennyiségi vizsgálatát. A feltárás alsó része, amely a szarmatába sorolható, alacsony diverzitású, normál tengeri együttest tartalmaz, melyben a Calcidiscus leptoporus, Reticulofenestra pseudoumbilicus, Sphenolithus moriformis és a Syracosphaera spp. voltak az uralkodó formák, és amelyben a Didemnidae családba tartozó előgerinchúros zsákállatok (aszcídiák) túi (Perforocalcinela fusiformis) is előfordulnak. A középső és késő miocén határa, azaz a szarmata/pannóniai határ a normál tengeri mészvázú nannofosszíliák utolsó előfordulásánál húzható meg. A feltárás felső részében az endemikus Isolithus spp. monospecifikus előfordulásával, illetve aszcídiákkal jellemzett intervallumok váltakoznak. A feltárás tetején egy rövid szakaszon gyakoriak a Noelaerhabdaceae családba tartozó endemikus kokkolitok (Bekelithella echinata, Noelaerhabdus bozinovicae, N. jerkovici, Praenoelaerhabdus banatensis). A nannofosszília-együttesek drasztikus változását a szarmata/pannóniai határon a Középsô-Paratethys lefüződésének következtében kialakult környezeti stressz okozta.

Kulcsszavak: szarmata, pannóniai, Pannon-tó, mészvázú nannofosszília, biosztratigráfia, paleoökológia

\begin{abstract}
Quantitative analyses on calcareous nannofossils were carried out on 109 middle/late Miocene (Sarmatian/Pannonian) samples from the section at Pécs-Danitzpuszta sand pit (Hungary). The lower part of the section, which can be assigned to the Sarmatian, contains normal marine low-diversity assemblages dominated by Calcidiscus leptoporus, Reticulofenestra pseudoumbilicus, Sphenolithus moriformis and Syracosphaera spp. accompanied by didemnid ascidian spicules (Perforocalcinela fusiformis). The middle/late Miocene (Sarmatian/Pannonian) boundary is characterized by the last occurrences of normal marine calcareous nannofossils. The upper part of the section (Pannonian) can be subdivided into intervals characterized by monospecific endemic nannofossils Isolithus spp. and ascidians, respectively. A short interval with common endemic coccoliths belonging to the family Noelaerhabdaceae (Bekelithella echinata, Noelaerhabdus bozinovicae, N. jerkovici, Praenoelaerhabdus banatensis) in the uppert part of the profile was also documented. The drastic change in nannofossil assemblages at the Sarmatian/Pannonian boundary is a result of paleoenvironmental stress caused by the isolation of the Central Paratethys from the Eastern Paratethys.
\end{abstract}

Keywords: Sarmatian, Pannonian, Lake Pannon, calcareous nannofossils, biostratigraphy, paleoecology

\section{Introduction}

As a consequence of the rise of the Alpine mountain belt at around the Eocene/Oligocene boundary, the Tethys Ocean disappeared and the Mediterranean and Paratethys Seas were established as two different palaeogeographic units in central and southern Europe (RöGL 1998). This biogeo- graphic differentiation led to the development of the regional Paratethyan chronostratigraphic and geochronologic system (RöGL 1998, 1999). During the Sarmatian, which spans 12.7-11.6 Ma time interval (HARZHAuSER \& PILLER 2007), the Central Paratethys was connected only to the Eastern Paratethys (Steininger \& Wessely 2000). Subsequent isolation of the Central Paratethys from the Eastern 
Paratethys at the Sarmatian/Pannonian boundary led to the formation of Lake Pannon in the Pannonian Basin system (HARZhauser \& Piller 2007, and references therein). During the Pannonian Age (11.6-6.1 Ma, Harzhauser \& PILLER 2007), brackish conditions prevailed in the basin, which made it impossible to use the standard calcareous nannofossil zonation for the biostratigraphic subdivision of the upper Miocene and Pliocene sediments in the Pannonian Basin.

Coccolithophores are a major group of unicellular marine phytoplankton used worldwide for the biostratigraphic and palaeoecologic interpretation of marine sediments from the Jurassic to the Quaternary. Ecologic factors, such as water temperature, light regime, inorganic nutrient supply (nitrate, phosphate, trace elements and vitamins) and water stratification directly influence the distribution of calcareous nannoplankton as photosynthetic haptophyte algae, which live in the upper euphotic zone of oceans (WINTER \& SIESSER 1994). Generally, nannoplankton flourish in warm, well-stratified, oligotrophic, mid-ocean environments, although numerous species have a broad ecological tolerance (Bown \& Young 1998).

JERKOVIĆ $(1970,1971)$ introduced a new family (Noelaerhabdaceae) with a new genus (Noelaerhabdus) and new species from the Pannonian of the southern Pannonian Basin. BóNA (1964) and BóNA \& GÁL (1985) recognized the endemic character of Pannonian calcareous nannofossils by investigation of many localities in Hungary. They described the new genus Bekelithella with a new species, B. echinata, and another new species, Noelaerhabdus jerkovici, from sediments exposed in Pécs-Danitzpuszta (BóNA \& GÁL 1985). Pannonian sediments with Bekelithella echinata, Noelaerhabdus bozinovicae, N. bekei and N. jerkovici from the south-western part of the South Carpathians (Caransebeş-Mehadia Basin, Romania) were assigned to nannoplankton zones NN10/NN11 by MĂRUNȚEANU et al. (1994).
Calcareous nannoplankton are thought to contribute substantially to the material of offshore calcareous marls (often mentioned as "white marls," especially in Croatia and Serbia) of Lake Pannon (Ćorić 2004, 2005a).

Calcareous nannofossils from Sarmatian and Pannonian deposits of various localities in the North Croatian Basin were investigated by GaLović \& Young (2012) and GaloVIĆ (2017). MĂRUNȚEANU et al. (1994) and MĂRUNȚEANU (1997) investigated Pannonian calcareous nannofossils from the Pannonian outcrops in the Transylvanian Basin (Romania) and established the evolutionary lineage of the genus Noelaerhabdus. This lineage can be used as a basis for the biostratigraphic subdivision of the Pannonian by calcareous nannofossils.

According to the regional Central Paratethyan chronostratigraphy (RöGL 1998, 1999), the middle Miocene is subdivided into the marine Badenian and Sarmatian Stages, which comprise nannoplankton zones NN4 - lower NN7 (MARTINI 1971). The Pannonian regional stage includes the entire upper Miocene and can be correlated to zones upper NN7 - NN11.

In this paper a detailed investigation of calcareous nannofossils from the middle-upper Miocene Pécs-Danitzpuszta section (Hungary) is documented. The objective of this study was to infer the stratigraphic position of the exposed succession, and to record and interpret the palaeoecological changes across the profile.

\section{Geological setting}

The Danitzpuszta outcrop, located in the eastern outskirts of the city of Pécs, is the largest exposure of Pannonian white marls in Hungary (Figure 1). The sand pit itself exposes upper Miocene Lake Pannon sediments: offshore
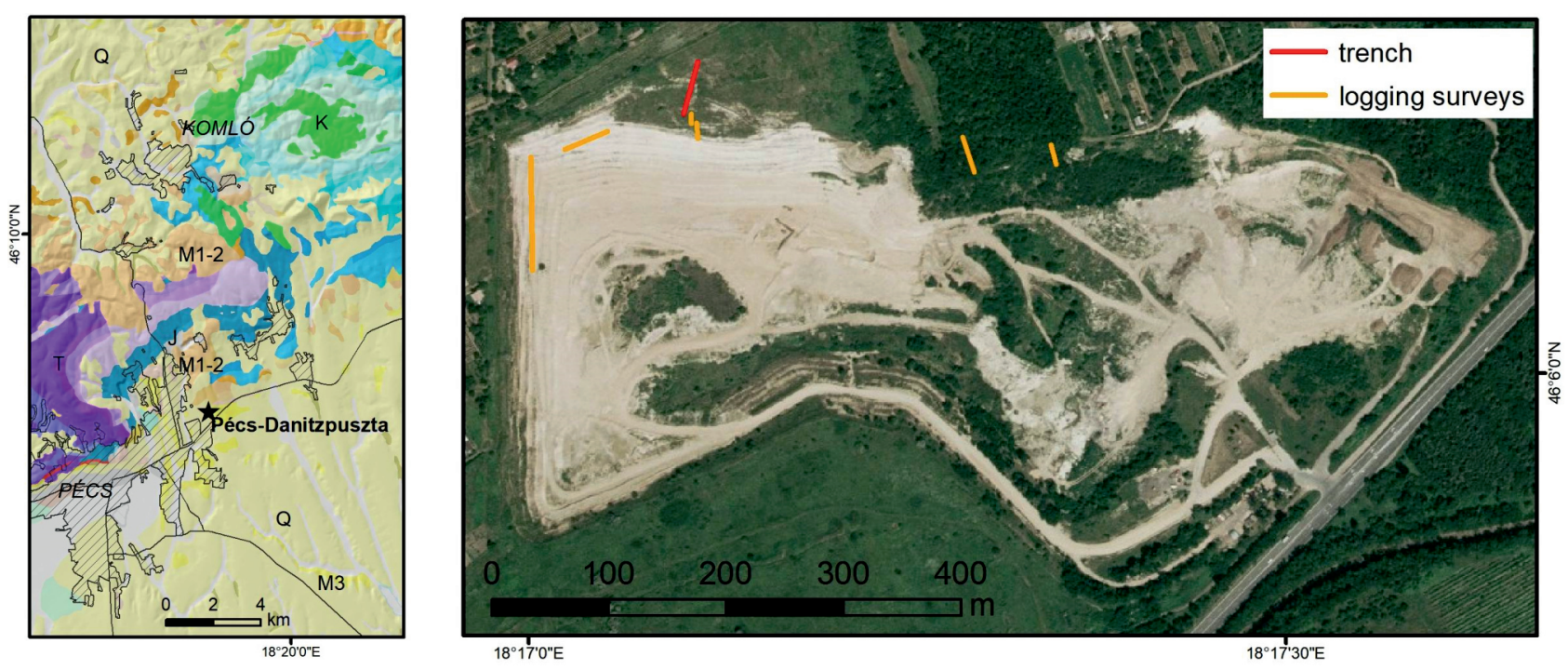

Figure 1. Location of the studied sand pit and the sampled sections

Legend: T (lilac): Triassic; J (blue): Jurassic; K (green): Cretaceous; M1-2: lower-middle Miocene; M3: upper Miocene; Q: Quaternary

1. ábra. A vizsgált feltárás helye a mintázott szelvényekkel

Jelmagyarázat: T(lila): triász; J(kék):jura; K(zöld): kréta; M1-2: alsó és középsö miocén; M3: felsö miocén; Q: kvarter 
calcareous marls with clay, clay marl and sand interbeds along the northern wall, and yellowish brown, limonitic coarse sands in the bulk of the pit. Due to tectonic deformation, the succession is tilted, thus the general younging direction of the deposits is towards the south. In 2018 an exploration trench was excavated in the northernmost part of the sand pit, which revealed middle Miocene (Badenian and Sarmatian) layers underlying the upper Miocene ones. For details on the exposed sediments, the reader is referred to SEBE et al. (2021).

\section{Material and methods}

In total 109 rock samples were analysed for calcareous nannofossils from the $12 \mathrm{~m}-79 \mathrm{~m}$ interval of the Pécs-Danitzpuszta outcrop, representing a total of $67 \mathrm{~m}$ stratigraphic thickness (Figure 2). Sampling covered the whole Sarmatian and Pannonian part of the section where appropriate lithologies - layers with carbonate content - were present. Sampling started with the first carbonate-bearing layer (D56) according to the numbering of SEBE et al. (2021), above the Badenian/Sarmatian boundary, defined by micropalaeontological investigations (SZUROMI-KORECZ et al., 2021).

Smear slides were prepared for all samples using standard procedures described by PERCH-NIELSEN (1985) and examined under light microscope DMLP Leica using planeand cross-polarized light with 1000x magnification.

Quantitative data were obtained by counting at least 300 specimens from each smear slide that contained calcareous nannofossils. Further 100 fields of view of each smear slide were checked for important markers for the biostratigraphic and palaeoecologic interpretation of calcareous nannoplankton (Digital annex). Table I contains an alphabetically arranged list of autochthonous calcareous nannofossils from the Pécs-Danitzpuszta section.

For the reticulofenestrids, the classification proposed by nannotax3 (http://www.mikrotax.org/Nannotax3/) was applied. The following Reticulofenestra species were distinguished: R. minutula (GARTNER, 1967) HAQ \& BERGGREN, 1978 (3-5 um without slits), R. haqii BACKMAN, 1978 (3-5 $\mu \mathrm{m}), R$. perplexa (BURNS, 1975) WISE, 1983, R. cf. rotaria THEODORIDIS, 1984 (subcircular to circular 5-7 $\mu \mathrm{m}$ ), $R$. pseudoumbilicus (GARTNER, 1967) GARTNER, 1969 (5-7 $\mu \mathrm{m})$ and $R$. pseudoumbilicus $(>7 \mu \mathrm{m})$.

Subdivision of genus Noelaerhabdus on the species level (Noelaerhabdus bekei JeRKović, 1971, N. bozinovicae JERKOVIĆ, 1970, N. jerkovici BóNA \& GÁL, 1985, N. mehadiscus MarunteAnU, 1996 and N. bonagali MARUnTEANU, 1995) is based on the shape and length of the central spine. During the preparation, the central spine usually became damaged or broken and, therefore, species of this genus can be easily confused with Praenoelaerhabdus banatensis that does not possess the central spine. Therefore, P. banatensis and Noelaerhabus spp. were counted together for statistical treatment. Coccoliths with diameter smaller than $3 \mu \mathrm{m}$ with closed central area were assigned to Praenoelaerhabdus small.
Simple statistical analyses were calculated with EXCEL, whereas complex analyses were performed using the program PAST 4.03.

Clustering of samples was performed by WARD's method based on standardized Euclidean distances with a subsequent determination of species that are indicative for the obtained clusters (see later Figure 4). Nonmetrical Multidimensional Scaling (nMDS), also based on standardized Euclidean distances, was used for the representation of the relationships between samples in a low-dimensional space (see later Figure 5). The grade of changes in nannofossil composition along the section was measured as distances between subsequent samples in the low dimensional character space gained by nMDS. Large distances indicate a strong turnover in floral composition, and longer intervals of large distances are typical for intensive environmental oscillations.

\section{Results}

Thirty-six of the 109 investigated smear slides were barren of calcareous nannofossils (Figure 2, Digital annex). Eleven samples contained too low amount of fossils; these were unsuitable for quantitative investigations. The rest of the samples (62 in total) contained generally common to abundant, well preserved calcareous nannofossils (Figure 3). All assemblages from the investigated section are characterized by low diversities, with a maximum value of 13 species in sample D41 (Figure 2).

According to the first and last occurrences of characteristic nannofossil species and based on their quantitative distribution patterns, the Pécs-Danitzpuszta section can be subdivided into three main intervals, which are further divided into subintervals (Figure 2, Digital annex).

Interval 1): from the lowermost sample to the last occurrence of Reticulofenestra pseudoumbilicus (GARTNER, 1967) GARTNER, 1969 (D56 to D35). This interval contains assemblages with normal marine nannofossils: Acanthoica cohenii (JERKOVIĆ, 1971) AUBRY, 1999, Calcidiscus leptoporus (MURRAY \& BlaCKMAN, 1898) LOEBLICH \& TAPPAN, 1978, Sphenolithus moriformis (BRÖNNIMANN \& STRADNER, 1960) BRAMLETTE \& WILCOXON, 1967, Syracosphaera spp., Braarudosphaera bigelowii (GRAN \& BRAARUD, 1935) DEFLANDRE, 1947 Braarudosphaera bigelowi subsp. parvula STRADNER, 1960, and Coccolithus pelagicus (WALLICH, 1877) SCHILLER, 1930). Barren samples from this interval probably point to short freshwater input. Interval 1 can be subdivided into two subintervals, each characterized by its own assemblage:

- Subinterval 1a): from the lowermost sample (D56) to D41 with the last common occurrence of Calcidiscus leptoporus as the upper boundary of this subinterval. Assemblages are rich in well-preserved nannofossils, accompanied by Syracosphaera spp. and didemnid ascidian spicules (sea squirts) assigned to Perforocalcinella fusiformis BóNA, 1964. The uppermost two samples (D42, D41) contain high amounts of Sphenolithus moriformis and Reticulofenestra pseudoumbilicus. Sediments from the upper part (D46 to 


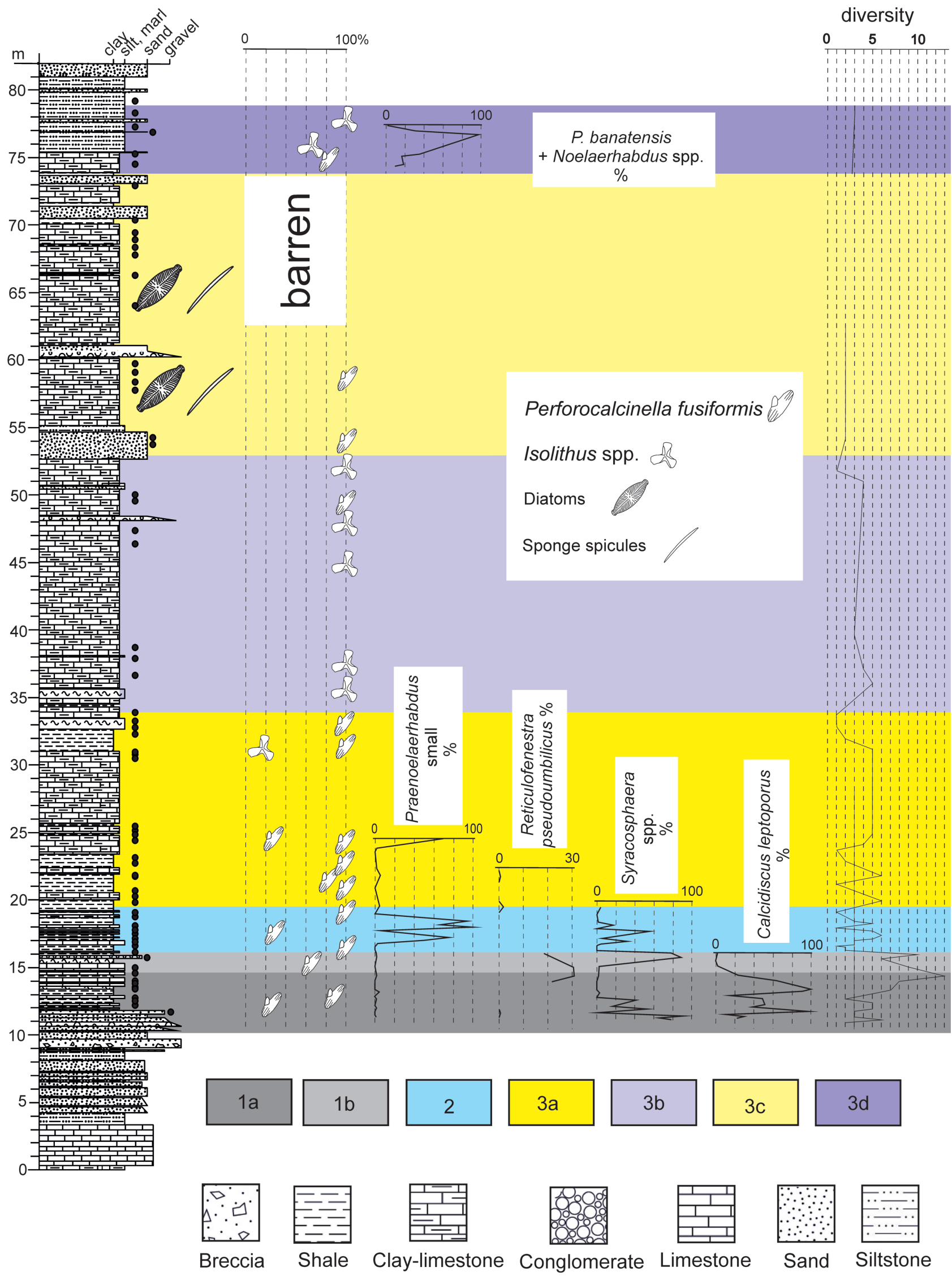

Figure 2. Sample locations and the subdivision of the Pécs-Danitzpuszta section based on calcareous nannofossils (clusters resulting from WARD's method - see Figure 4)

2. ábra. A pécs-danitzpusztai szelvény tagolása mészvázú nannofosszíliák alapján (a csoportok elkülönitése Ward módszerével történt, ld. 4. ábra) 
Table I. Distribution of autochthonous calcareous nannofossils in samples from the Pécs-Danitzpuszta section. The list is arranged in an alphabetical order

I. tábla. Az autochton mészvázú nannofossziliák eloszlása a pécs-danitzpusztai szelvény mintáiban (ábécésorrendben)

\begin{tabular}{|c|c|c|}
\hline Species & $\begin{array}{l}\text { Specimen } \\
\text { number }\end{array}$ & $\begin{array}{l}\text { Number of } \\
\text { samples }\end{array}$ \\
\hline Acanthoica cohenii (JERKOVIĆ, 1971) AUBRY, 1999 & 42 & 5 \\
\hline Bekelithella echinata BóNA \& GÁL, 1985 & 11 & 5 \\
\hline Braarudosphaera bigelowii (GRAN \& BRAARUD 1935) DEFLANDRE, 1947 & 2 & 2 \\
\hline Braarudosphaera bigelowi subsp. parvula STRADNER, 1960 & 13 & 5 \\
\hline Calcidiscus leptoporus (MURRAY \& BLACKMAN, 1898) LOEBLICH \& TAPPAN, 1978 & 1777 & 15 \\
\hline Calcidiscus pataecus (GARTNER, 1967) DE KAENEL \& VILLA, 1996 & 2 & 2 \\
\hline Calciosolenia brasiliensis (LOHMANN, 1919) Young in Young et al., 2003 & 7 & 2 \\
\hline Catinaster cf. calyculus MARTINI \& BRAMLETTE, 1963 & 1 & 1 \\
\hline Coccolithus pelagicus (WALLICH 1877) SCHILLER, 1930 & 27 & 15 \\
\hline Coronocyclus nitescens (KAMPTNER, 1963) BRAMLETTE \& WILCOXON, 1967 & 4 & 2 \\
\hline Helicosphaera carteri (WALLICH 1877) KAMPTNER, 1954 & 3 & 3 \\
\hline Isolithus pavelici ĆORIĆ , 2008 & 2582 & 25 \\
\hline Isolithus semenenko LYUL'EVA, 1989 & 2092 & 22 \\
\hline Isolithus spp. & 89 & 13 \\
\hline Lithostromation perdurum DEFLANDRE, 1942 & 1 & 1 \\
\hline Praenoelaerhabdus banatensis MıHAJLović 1993, Noelaerhabdus spp. & 625 & 7 \\
\hline Praenoelaerhabdus small $(<3 \mu \mathrm{m})$ & 1475 & 22 \\
\hline Perforocalcinella fusiformis BÓNA 1964 & 7691 & 49 \\
\hline Pontosphaera discopora SCHILLER, 1925 & 1 & 1 \\
\hline $\begin{array}{l}\text { Pontosphaera multipora (KAMPTNER, } 1948 \text { ex DEFLANDRE in DEFLANDRE \& FERT, 1954) } \\
\text { ROTH, } 1970\end{array}$ & 2 & 2 \\
\hline Pontoshaera sp. & 2 & 2 \\
\hline Reticulofenestra haqii BACKMAN, 1978 & 5 & 3 \\
\hline Reticulofenestra minutula (GARTNER, 1967) HAQ \& BERGGREN, 1978 & 4 & 2 \\
\hline Reticulofenestra perplexa (BURNS, 1975) WISE,1983 & 4 & 2 \\
\hline Reticulofenestra pseudoumbilicus >7 um (GARTNER, 1967) GARTNER, 1969 & 153 & 7 \\
\hline Reticulofenestra pseudoumbilicus 5-7 $\mu$ m (GARTNER, 1967) GARTNER, 1969 & 164 & 7 \\
\hline Reticulofenestra cf. rotaria THEODORIDIS, 1984 & 7 & 2 \\
\hline Sphenolithus moriformis (BRÖNNIMANN \& STRADNER, 1960) BRAMLETTE \& WILCOXON, 1967 & 144 & 5 \\
\hline Sphenolithus sp. & 2 & 1 \\
\hline Syracosphaera spp. & 1945 & 24 \\
\hline Thoracosphaera spp. & 16 & 7 \\
\hline
\end{tabular}

D41) are characterized by decrease in abundance of nannofossils.

- Subinterval $1 b$ ): from D40 to D35, between the last occurrence of $C d$. leptoporus and the last continuous occurrence of Reticulofenestra pseudoumbilicus. Assemblages of this subinterval contain rare but well-preserved nannofossils dominated by $R$. pseudoumbilicus, Syracosphaera spp. and $P$. fusiformis.
Interval 2 (clay-marl-limestone alternation): From the last occurrence of $R$. pseudoumbilicus to the last occurrence of Syracosphaera spp. (D34 to D20). Assemblages from this interval are dominated by small-sized noelaerhabdaceae (with a diameter of $3 \mu \mathrm{m}$ or less) assigned to Praenoelaerhabdus small, P. fusiformis, and Syracosphaera spp. This assemblage is accompanied by very rare $A$. cohenii, $C$. pelagicus and $R$. pseudoumbilicus. Spora- 


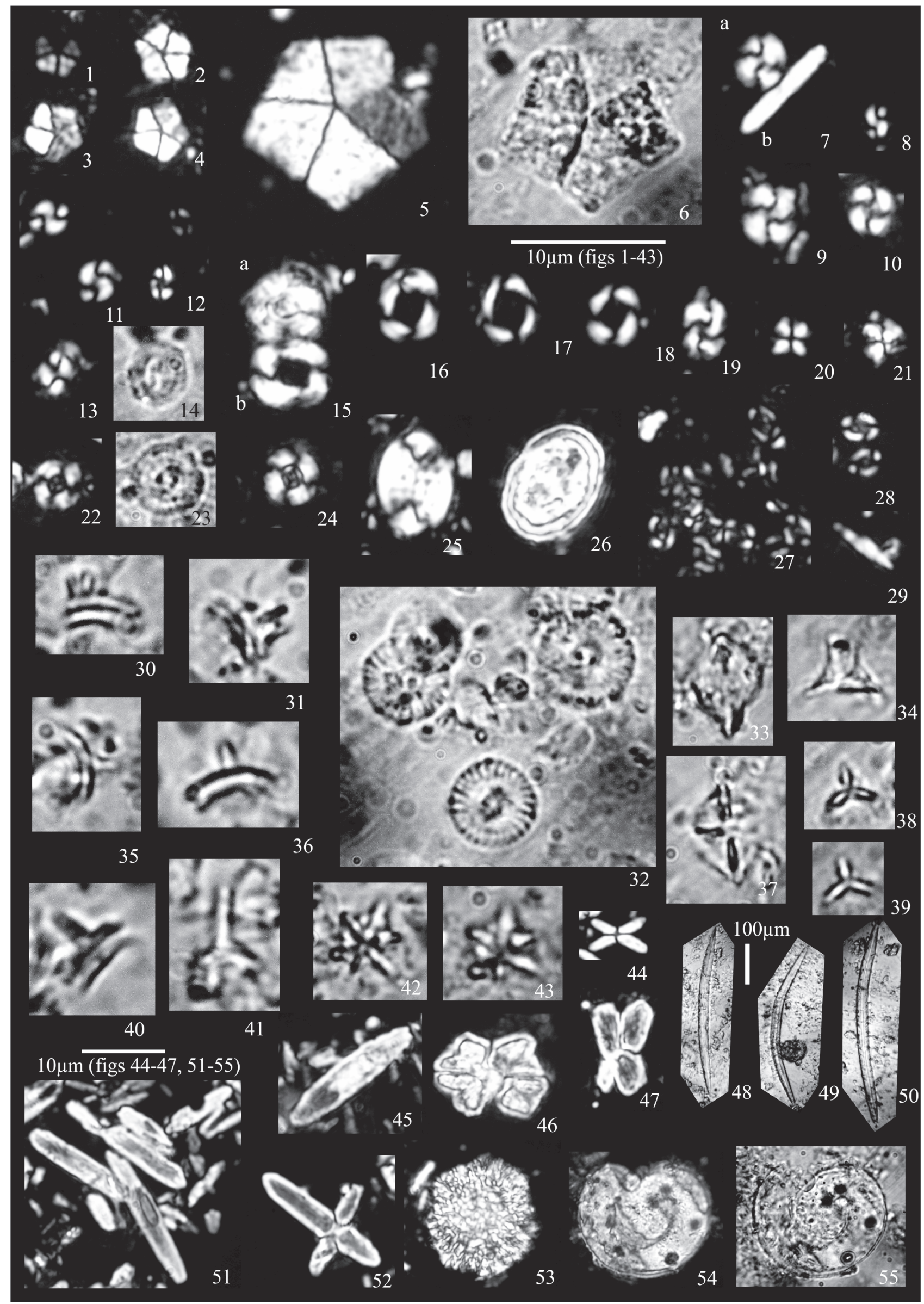


dically, occurrences of these species can be a result of reworking.

Interval 3): the upper part of the section in a thickness of ca. $61 \mathrm{~m}$ (D19 to D225E). This interval is characterized by blooms of didemnid ascidian spicules (P. fusiformis) and endemic nannofossils belonging to the genus Isolithus (Isolithus pavelici, Isolithus semenenko, Isolithus spp.). Samples D219W to D223-2 contain endemic Praenoelaerhabdus banatensis MiHAJLović, 1993 (taxa without central spine), Noelaerhabdus bekei JERKOVIĆ, 1971 (short spine in the central area), N. jerkovici BóNA \& GÁL, 1985 (longer spine) and Bekelithella echinata BóNA \& GÁL, 1985. Normal marine nannofossils (A. cohenii, Catinaster cf. coalitus, C. pelagicus, $R$. perplexa, $R$. haqii, $R$. pseudoumbilicus etc.) are very rare in this interval. Interval 3 can be subdivided into the following four subintervals based on the alternating predominance of ascidians and Isolithus spp., respectively.

- Subinterval 3a) from sample D19 to D5 (between the last occurrence of Syracosphaera spp. and first common occurrence of Isolithus spp.) is characterized by blooms of ascidians, whereas the dominance of Praenoelaerhabdus small was observed only in sample D11, and by the very scarce presence of normal marine taxa $(C$. pelagicus, $R$. haqi, $R$. minutula, $R$. perplexa).

- Subinterval 3b): from sample D1 to D117W contains assemblages with the blooms of Isolithus spp. with sporadically abundant ascidians (sample D116).

- Subinterval 3c): from sample D118 to D217. In the lower part of this interval (D118 to D207) ascidians occur accompanied by diatoms and sponge spicules, whereas the upper part is barren and does not contain any fossils (D209-D217).

Figure 3. Calcareous nannofossils from the Pécs-Danitzpuszta section

3. ábra. Mészvázú nannofosszíliák a pécs-danitzpusztai szelvényböl

1-4. Braarudosphaera bigelowi subsp. parvula STRADNER, 1960, D36.

5, 6 Braarudosphaera bigelowii (GRAN \& BRAaRUd, 1935) DeFLANDRE, 1947, D41.

7a, 9, 10. Praenoelaerhabdus banatensis Miнajlović, 1993, D219.

7b. Didemnid ascidian spicule, D219.

8, 11, 12. Praenoelaerhabdus small (<3um), 11: Sample D-219; 8, 12 . D11.

13, 14. Coccolithus pelagicus (WALLICH, 1877) SCHILLER 1930, D41.

15a, 22-24, 32. Calcidiscus leptoporus (MuRRAY \& BLACKMAN, 1898) LoEBlich \& TAPpAN, 1978, 15a: Sample D-39; 22-25, 37: D47.

15b, 16-18. Reticulofenestra pseudoumbilicus (GARTNER, 1967) GARTNER, 1969, 15b: Sample D-39, 16, 17: Sample D-35, 18: D41.

19. Reticulofenestra perplexa (BuRNs, 1975) WISE, 1983 D41.

20, 21. Sphenolithus moriformis (BRönNimann \& StRadner, 1960) BRAmLetTe \& WILCoxon, 1967, Sample D-25; 28: D41.

25. Pontosphaera multipora (Kamptner, 1948 ex Deflandre in Deflandre \& FerT, 1954) Roth 1970, D221.

26. Pontosphaera discopora SCHILLER, 1925, D25.

27, 28. Syracosphaera spp., D54.

29. Calciosolenia brasiliensis (LoHmann, 1919) Young in Young et al. 2003, D55.

30, 31. Bekelithella echinata BóNA \& GÁL, 1985, D221.

33, 37. Isolithus pavelici ĆorIĆ, 2005, Figs 33, 45: D107; Figs 33, 44: D102.

34. Acanthoica sp.

35, 36, 40. Noelaerhabdus bekei JeRKović, 1971, D 221.

38, 39. Isolithus semenenko LuLJEWA, 1989, D102.

41. Noelaerhabdus jerkovici BónA \& GÁL, 1985, D221.

42, 43. Catinaster calyculus Martini \& BRAmLETte, 1963, D221.

44-47, 51, 52. Didemnid ascidian spicules: Perforocalcinella fusiformis BóNA, 1964, 4547.: D6; 43, 51, 52: D36.

48-50. Loose demosponge spicules, different types of oxeas, D204-3

53. Calcifying dinoflagellates (Thoracosphaera spp.), D25.

54, 55. Planktonic gastropods, D25.
- Subinterval 3d) includes samples from the top of the section (D219W to D225E). This short interval (ca. $4 \mathrm{~m}$ ) is characterized by occurrences of endemic calcareous nannofossils belonging to family Noelaerhabdaceae JERKOVIĆ, 1970 emend. Young \& Bown, 1997: Bekelithella echinata, Praenoelaerhabdus banatensis, Noelaerhabdus bekei, $N$. bozinovicae, $N$. jerkovici in samples D219 to D223-1 cooccurring with ascidians. Subinterval 3d ends with samples containing Isolithus spp. (Samples D223 and D225).

Thin green clay/silt layers from the top of the profile Pécs-Danitzpuszta (D226, D226E) are barren of calcareous nannofossils.

Very rare occurrences of Watznaueria barnesiae (BLACK in Black \& Barnes, 1959) Perch-Nielsen, 1968, Micula staurophora (GARDET, 1955) STRADNER, 1963 and Nannoconus steinmannii KAMPTNER, 1931 throughout the whole section point to reworking from the Cretaceous.

\section{Species distribution by multivariate analyses}

Cluster analysis by the Euclid method differentiated three clusters (Figure 4).

A single species, Perforocalcinella fusiformis, is an indicator component for clustering samples into Cluster 1 . This cluster includes 25 samples mostly from interval 2 and from subintervals $3 \mathrm{a}$ and $3 \mathrm{c}$. All samples from this cluster are grouped in the $4^{\text {th }}$ quadrant of nMDS (Figure 5).

High percentages of endemic genus Isolithus spp. characterize Cluster 2, which groups in total 14 samples exclusively from Subintervals $3 \mathrm{~b}$ and $3 \mathrm{~d}$. Samples from Cluster 2 are placed in the $3^{\text {rd }}$ quadrant of nMDS (Figure 5).

Most significant species in Cluster 3 are Calcidiscus leptoporus, Syracosphaera spp., Sphenolithus moriformis, $R$. pseudoumbilicus and Praenoelorhabdus small. This cluster contains samples from Subintervals 1a (11 samples), $1 \mathrm{~b}$ (2 samples), Interval 2 (6 samples), Subinterval 3d (with $B$. echinatta, Praenoelaerhabdus banatensis and Noelaerhabdus spp.) and only one sample from Interval 3a. Samples from Cluster 3 are grouped in the central part of nMDS (Figure 5).

\section{Discussion}

\section{Palaeoecology}

The interpretation of the palaeoenvironment is based on the changes in abundance patterns of nannofossils within assemblages. All samples contain very low diversity assemblages with higher values in the lower part of the section (Intervals 1 and 2 with a maximum value of 13 taxa in D41, Figure 2). Assemblages from the middle and upper part of the section (Intervals $3 \mathrm{a}-\mathrm{d}$ ) consist mostly of only one or two species. Calcareous nannofossil assemblages from the lower part of the section (Intervals 1 and 2) are defined by Calcidiscus leptoroporus, Reticulofenestra pseudoumbilicus, Syracosphaera spp. and Praenoelaerhabdus small as 

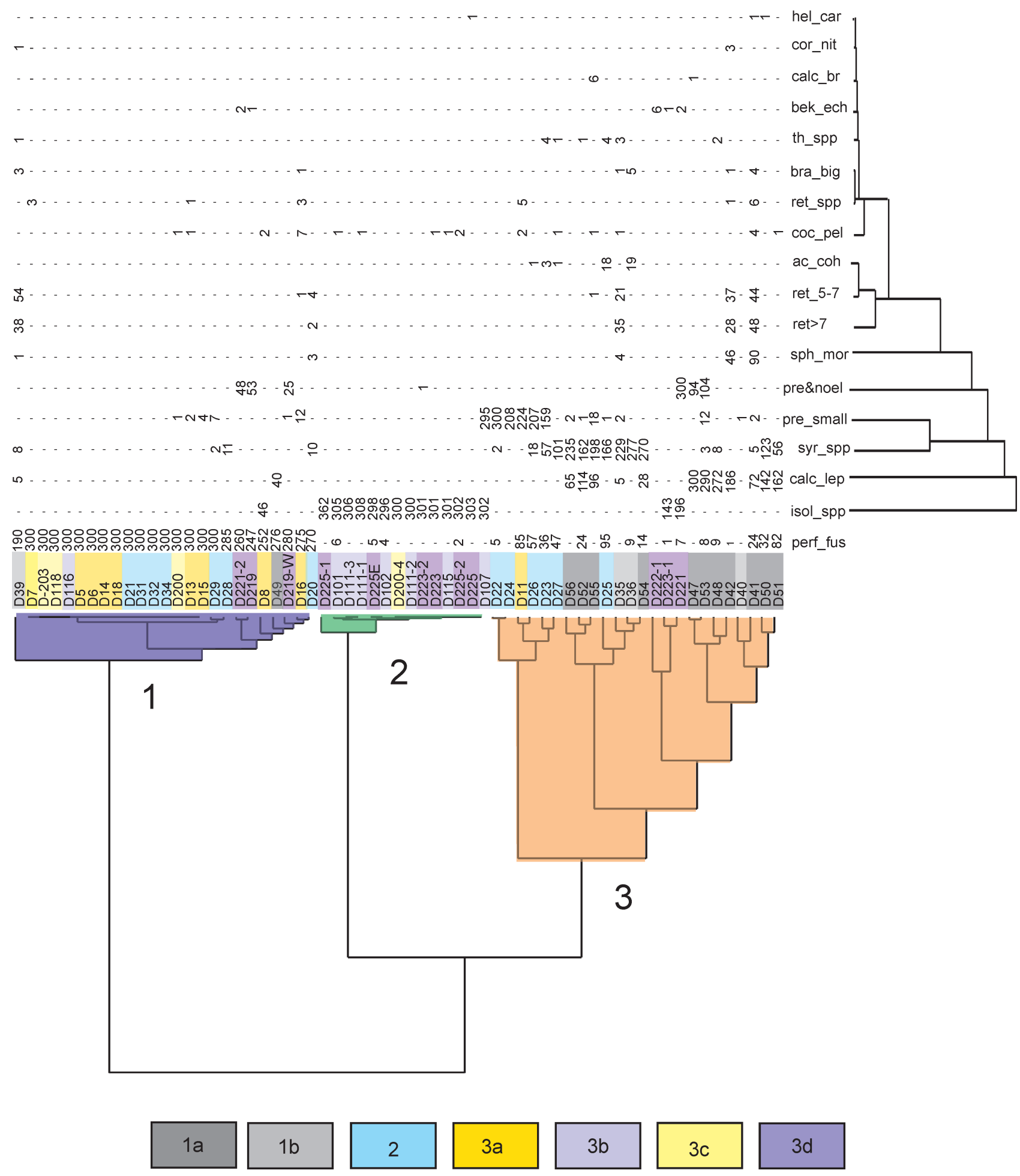

Figure 4. Dendrogram of sample clusters resulting from WARD's method 4. ábra. A vizsgált minták dendrogramja (WARD módszere alapján)

main components. Isolithus spp. and didemnid ascidians are dominating components in the upper part of the section in Interval 3.

Didemnid ascidian spicules are generally common and well-preserved in basins characterised by high bottom water temperature, rapid sedimentation rate and low water circu- lation (VArol \& Houghton 1996). Perforocalcinella fusiformis that belongs to this group was described from the lower Pannonian of the Mecsek Mountains (borehole Hidas), Hungary (BónA 1964). Blooms of P. fusiformis were also documented from the upper Sarmatian in different parts of the Central Paratethys (GAlović 2017, Ćorić et al. 2017) 


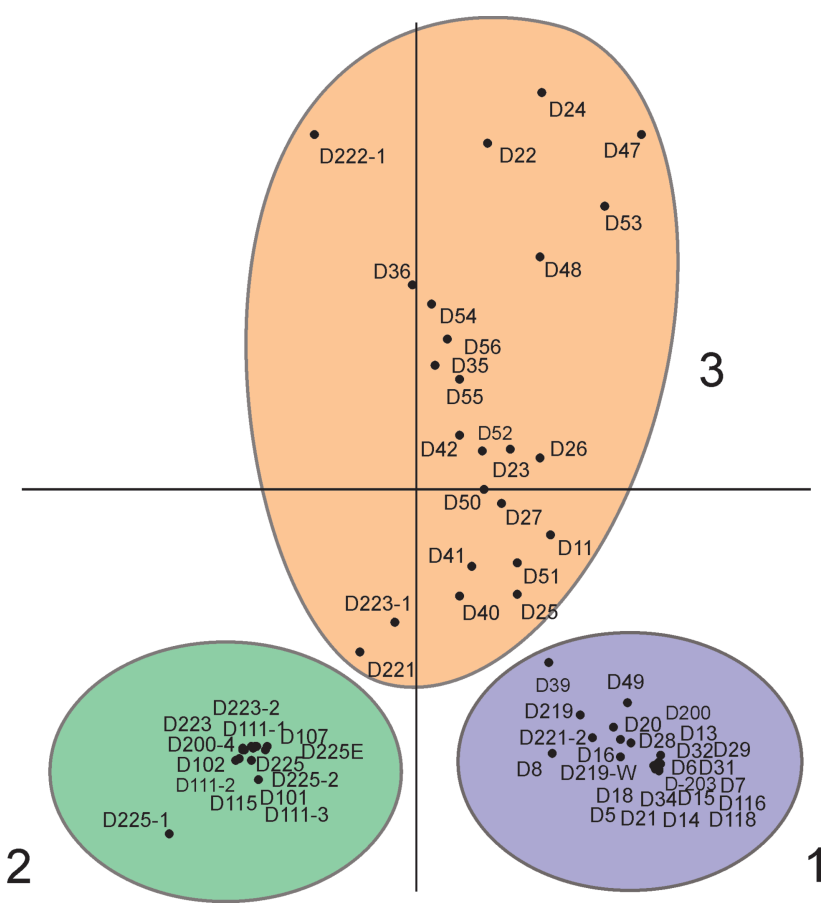

Figure 5. Nonmetrical Multidimensional Scaling (nMDS) of samples

5. ábra. A minták eloszlása nem-metrikus többdimenziós skálázási módszerrel (nMDS)

and, as sporadic occurrences, from the Badenian (Kovéč et al. 2005, 2008). The changes in occurrences of $P$. fusiformis are strongly influenced ecologically by changes in palaeoconditions and cannot be used for biostratigraphic subdivision.

Interval 1 with the highest diversity throughout the section (average value 5.12 taxa/sample) contains assemblages with normal marine nannofossils.

Subinterval $1 a$ is dominated by Calcidiscus leptoporus, an extant taxon with the first occurrence within NN2 (lowermost Aquitanian) and still present in recent oceans. Ecological preferences of $C$. leptoporus were investigated in Portuguese coastal water by SiLVA et al. (2009). This opportunistic cosmopolitan coccolithophore species points to warmer, low turbulent, normal salinity, oligotrophic waters. High occurrences of warm oligotrophic S. moriformis on the top of Subinterval 1a (samples D42 and D41) point to a short interval of increased salinity during Sarmatian. The absence or only sporadic occurrence of Coccolithus pelagicus, which is well-known as a marker of nutrient-rich cold water (OKADA \& MCINYRe 1979, Winter \& Siesser 1994), and those of helicoliths with ecological preference for upwelling (PERCh-Nielsen 1985, Rahman \& Roth 1990) support this interpretation.

In Subinterval 1b, Calcidiscus leptoporus is replaced by large R. pseudoumbilicus $(>7 \mu \mathrm{m})$. The abundance of this species, together with the occurrences of B. bigelowii in the top of Subinterval 1a and throughout Subinterval 1b, points to a period of increased eutrophy within the Sarmatian. Increased nutrient supply was probably caused by more intense river runoff. Abundant occurrences of B. bigelowii may point to decreased salinity; however, this species never exceeds $2 \%$ in nannofossil assemblages from Pécs-Danitzpuszta outcrop. Braarudosphaera bigelowii is predominantly observed in neritic and shelf seas (PERCH-NIELSEN 1985). An increase in species diversity from Subinterval 1a to Subinterval $1 \mathrm{~b}$ confirms a raise in the nutrient supply in the upper part of Interval 1. Common occurrences of C. leptoporus, Syracosphaera spp., and reticulofenestrids accompanied with ascidians were also reported from the upper Sarmatian sediments from other parts of the Central Paratethys (GALOviĆ 2017, ŠARINOVÁ et al. 2018), and are interpreted as a consequence of decreasing water depth at the end of the middle Miocene (as documented by e.g., PILLER et al. 2007).

Samples from Interval 1 are grouped into Cluster 3 (Figure 4) occupying the central and the upper part of nMDS, and biostratigraphically can be attributed into the Sarmatian.

Interval 2 represents a thickness of ca. $3 \mathrm{~m}$ and contains very low diversity assemblages with an average value of 3.14 taxa/sample. The lower part of this interval (D34 to D28) is dominated by ascidians, whereas in the upper part (D27 to D23) Praenoelaerhabdus small and Syracosphaera spp. prevail. Acanthoica cohenii and ascidians are also common.

Genus Praenoelaerhabdus with P. banatensis is an endemic taxon described from Pannonian deposits of Serbia (MinaJlović 1993). Small Praenoelaerhabdus with a diameter less than $2 \mu \mathrm{m}$ were documented from the Sarmatian and Pannonian of Croatia (Ćorić et al. 2017). Blooms of small Praenoelaerhabdus together with Syracosphaera spp. during Interval 2 can be interpreted as a period of strongly reduced salinity. It represents a transitional interval containing normal marine (A. cohenii and Syracosphaera spp.) and endemic forms (Praenoelaerhabdus small) in a low diversity association. Samples of Interval 2 containing ascidians are grouped into Cluster 1, whereas samples with coccoliths (Syracosphaera spp, and Praenoelaerhabdus small) were statistically grouped into Cluster 3 .

The longest part of the section (ca. $61 \mathrm{~m}$ ) belongs to $\mathrm{In}$ terval 3 , which is subdivided into four subintervals according to the predominance of $P$. fusiformis (Subintervals 3a and 3c), Isolithus spp. (3b and 3d) or P. banatensis and Noelaerhabdus spp., respectively. Isolithus semenenko LuLJEWA, 1989 was originally described from the lower Pliocene marls of the Eastern Paratethys (Taman region, Russia). The occurrences of this genus were documented in the uppermost Sarmatian and Pannonian sediments of the Central Paratethys in Croatia, Serbia and Romania (ĆoRIć et al. 2017, Galović 2017). Chira \& Malacu (2008) reported about the abundance of various Isolithus species in the Pannonian of Transylvania (Romania). ĆORIĆ (2004, 2005a, b) investigated quantitatively the calcareous nannofossils from the Pannonian of Croatia (Našice) and found periodically repeated blooms of Isolithus spp. alternating with periods of blooms of $P$. fusiformis. Periods with blooms of ascidian spicules ( $3 \mathrm{a}$ and $3 \mathrm{c}$ ) can be interpreted as periods of shallowing whereas intervals with abundant Isolithus spp. (3b and 3d) can point to the opposite trend. Results of quantitative analyses can be used for the correlation 
between various locations and sub-basins within the Pannonian Basin.

Samples from Subintervals $3 a$ and $3 c$ (dominated by $P$. fusiformis) are mostly grouped into Cluster 1 together with samples from Intervals 1 and 2, which have similar composition, thus they cannot be separated from each other stratigraphically. On the other hand, samples containing Isolithus spp. (Subintervals $3 b$ and $3 d$ ) build Cluster 2 (Figure 4), clearly separated in the lower left part of the nMDS diagram (third quadrant).

The middle part of Subinterval 3c (D200-1 to D207) is characterized by the occurrences of well-preserved diatoms and sponge spicules. HAJós (1985) investigated occurrences of Pannonian diatoms from several localities in Hungary. All occurrences may point to sedimentation in very shallow areas, or lagoons dominated by NW wind. The investigated diatom assemblages are very often accompanied by sponge remains. Occurrences of sponge remains can be a sign of extremely stressing conditions, such as water level variation (MANCONI \& PROZANTO 2015, 2016). Therefore, Subinterval $3 \mathrm{c}$ in the Pécs-Danitzpuszta section can be interpreted as a period of strong shallowing. Interestingly, freshwater sponge remains (Ephydatia fossilis) were first described from the middle/upper Miocene from Hungary (Dubrovicza) and Romania (Kevna Bremia) by TrAXLER (1894).

Subinterval $3 d$ contains rich, well-preserved assemblages. The lower part of this Subinterval is dominated by the co-occurrence of ascidians and endemic nannofossils, such as Bekelithella echinata, Praenoelaerhabdus banatensis, Noelaerhabdus bekei and Noelaerhabdus jerkovici. Occurrences of placoliths from family Noelaerhabdaceae is a sign of short deepening of this part of the basin. Subinterval $3 \mathrm{~d}$ ends with blooms of Isolithus spp.

\section{Biostratigraphy}

Generally, the Pécs-Danitzpuszta section can be subdivided into a lower part (Intervals 1 and 2 including samples D56 to D20) with normal marine calcareous nannofossils, and an upper part (Interval 3 including samples D18 to D225) characterized by the presence of ascidians and endemic nannofossils and very rare marine nannofossils.

In the lower part of the section, the absence of Sphenolithus heteromorphus DEFLANDRE, 1953 points to an age younger than NN5 (MARTINI 1971). Interval 1b contains a high amount of R. pseudoumbilicus (up to $30 \%$ of total nannofossils and about $90 \%$ of all counted reticulofenestrids). FoRNACIARI et al. (1996) used common and abundant R. pseudoumbilicus to define the Reticulofenestra pseudoumbilicus Partial-range Subzone (MNN6b) in the Mediterranean region, which can be correlated with the upper part of standard nannoplankton Zone NN6. RAFFI et al. (2006) dated Highest Occurrence (HO) of Cyclicargolithus floridanus (RоTн \& HAY in HAY et al. 1967) BUKRY 1971 at 12.1 Ma in the uppermost Serravallian. The absence of $C$. floridanus in all investigated samples allows an attribution of the lower part of the section (D56 to D20) to the upper NN6 or younger, which can be correlated to the upper Sarmatian. The zone marker for NN7, Discoaster kugleri MARTINI \& BRAMLETTE, 1963, was not observed in the section. The absence of discoasters (open marine taxa) is most probably caused by the shallowing environment during the Sarmatian in this area. According to the last continuous occurrence of marine nannofossils, the Sarmatian-Pannonian boundary can be placed between samples D20 and D19. Sample D36 contains common Braarudosphaera bigelowi subsp. parvula STRADNER 1960. Bloom of this small pentalith was observed in the upper Sarmatian of the southern Vienna Basin (STRADNER 1960) and was interpreted as the result of a drop in salinity. Occurrences of this species confirm the attribution of this part of the section into the upper Sarmatian.

The lower part of Subinterval 3d (samples D219 to D223) is characterized by high amounts of ascidians, endemic coccoliths Bekelithella echinata, Praenoelaerhabdus banatensis, Noelaerhabdus bekei, Noelaerhabdus jerkovici and only sporadic occurrences of normal marine species; thus, it can be attributed to the Pannonian. MĂRUNȚEANU (1997) proposed an evolutionary lineage for the endemic Noelaerhab$d u s$ species in Transylvania. Due to the shallow position of the section, only the nannofossil assemblages from the uppermost part of the Pécs-Danitzpuszta section (Subinterval 3d) fit this proposed model. According to MĂRUNȚEANU et al. (1994), a similar endemic assemblage occurs above marine species that represent the NN9 zone in the Temes Valley, Romania. Thus, the endemic assemblage must be younger than the beginning of NN9 Chron (10.55 Ma). Sample D221 contains the very rare Catinaster cf. calyculus MARTINI \& BRAMLETTE, 1963. This cup-shaped nannofossil has a short stratigraphic range with the first occurrence within NN9 and the last occurrence within NN10. Therefore, this part of the section can be correlated either with NN9 $(9.53-10.55 \mathrm{Ma})$ or with NN10 (8.29-9.53 Ma).

\section{Conclusions}

All samples from the Pécs-Danitzpuszta outcrop contain low-diversity calcareous nannofossil assemblages. The section can be divided into three intervals that reflect palaeoecological changes during the late Sarmatian and Pannonian period. Interval 1 (samples D56 to D35) is dominated by normal marine nannofossils, such as $C$. leptoporus, $R$. pseudoumbilicus, S. moriformis, Syracosphaera spp., and by didemnid ascidian spicules (sea squirts). This assemblage points to warm, shallow oligotrophic marine conditions. A slight increase in eutrophication in the upper part (Subinterval 1b) is probably caused by enhanced nutrient supply by rivers. Interval 2 (D34 to D20) displays very low diversity. The cooccurrence of endemic Praenoelaerhabdus small and normal marine A. cohenii and Syracosphaera spp. indicates a drop in salinity, which can be interpreted as a stepwise transition from marine to brackish lacustrine conditions. The longest interval, Interval 3 (D18 to D225) is characterized by alternation of monospecific assemblages with either P. fusiformis or Iso- 
lithus spp. Assemblages dominated by ascidians (P. fusiformis) are interpreted as periods of shallowing based on the cooccurrences of diatoms and sponge remains within this inter$\operatorname{val}(3 \mathrm{c})$. On the contrary, the intervals with abundant Isolithus spp. are interpreted as periods of slight deepening. In addition, a short interval (lower part of 3d) with endemic calcareous nannofossils (B. echinata, Noelaerhabdus spp.) also indicate a period of deepening of the basin. Changes in the Pannonian assemblages are influenced by changes in environmental circumstances, most probably water depth and salinity.

Based on the abundance of R. pseudoumbilicus and the absence of $S$. heteromorphus and $C$. floridanus, Intervals 1 and 2 can be attributed to the upper NN6 (and/or NN7) standard nannoplankton zones (younger than 12.1 Ma), and are interpreted here as belonging to the marine upper Sarmatian, whereas Interval 3 correlates with the brackish lacustrine Pannonian. Based on the occurrences of Bekelithella echinata and species belonging to the genus Noelaerhab$d u s$, the upper part of the section is attributed to NN10 nannozone. Our investigations show that quantitative assessment of endemic calcareous nannofossils might be a tool for stratigraphic correlation within the Pannonian.
The applied statistical methods document the response of nannofossil assemblages to the rapid environmental and paleoecological changes that took place during the Sarmatian and Pannonian in this part of the Pannonian Basin.

\section{Acknowledgments}

I would like to thank Krisztina Sebe (University of Pécs) for providing the samples from the Pécs-Danitzpuszta section. I am very grateful to reviewers Imre Magyar (MOL Hungarian Oil and Gas Company, Budapest), Ottilia SzIves (Hungarian Natural History Museum, Budapest), Eva Halásová (Comenius University, Bratislava) and Orsolya SzTANó (Eötvös Loránd University, Budapest) for contributing to the quality of this paper with their advices. Many thanks to Imre MAGYAR for the constructive discussion and the translation of the abstract into Hungarian language. These investigations were supported by the Hungarian National Research, Development and Innovation office (NKFIH) project 116618.

\section{References - Irodalom}

AUBRY, M.-P. 1999: Handbook of Cenozoic calcareous nannoplankton. Book 5: Heliolithae (Zygoliths and Rhabdoliths). - Micropaleontology Press, American Museum of Natural History, New York. 1-368.

BACKMAN, J. 1978: Late Miocene - Early Pliocene nannofossil biochronology and biogeography in the Vera Basin, SE Spain. - Stockholm Contributions in Geology 32, 93-114.

BLACK, M. \& BARNES, B. 1959: The structure of Coccoliths from the English Chalk. - Geological Magazine 96/5, 321-328.

BÓNA, J. 1964: Coccolithophoriden-Untersuchungen in der neogenen Schichtenfolge des Mecsek-gebirges. - Földtani Közlöny 94, 121-131.

BÓNA, J. \& GÁL, M. 1985: Kalkiges Nannoplankton im Pannonien Ungarns. - In: PAPP, A., JÁMBOR, Á. \& SteInINGER, F. (eds): Miozän der Zentralen Paratethys VII, M6, Pannonien. - Chronostratigraphie und Neostratotypen 1985, Akadémiai Kiadó, Budapest, $482-515$.

Bown, P. R. \& Young, J. R. 1998: Introduction. - In: Bown, P. R. (ed.): Calcareous Nannofossil Biostratigraphy. - Kulwer Academic Publications, Dordrecht, Netherlands, 1-15.

Bramlette, M. N. \& Wilcoxon, J. A. 1967: Middle Tertiary calcareous nannoplankton of the Cipero section, Trinidad, W.I. - Tulane Studies in Geology and Paleontology 5, 93-131.

BRÖNNIMANN, P. \& STRADNER, H. 1960: Die Foraminiferen- und Discoasteriden-zonen von Kuba und ihre interkontinentale Korrelation. Erdoel-Zeitschrift 76/10, 364-369.

BUKRY, D. 1971: Cenozoic calcareous nannofossils from the Pacific Ocean. - San Diego Society of Natural History Transactions 16, $303-327$.

BuRns, D. A. 1975: Distribution, abundance, and preservation of nannofossils in Eocene to Recent Antarctic sediments. - New Zealand Journal of Geology and Geophysics 18/4, 583-595.

ChIRA, C. \& MAlaCU, A. 2008: Biodiversity and paleoecology of the Miocene calcareous nannoplankton from Sibiu area (Transylvania, Romania). - Acta Palaeontologica Romaniae 6, 17-28.

ĆORIĆ, S. 2004: Occurences of endemical Pannonian calcareous nannoplankton genus Isolithus Luljeva, 1989 in the Central Paratethys. - Scripta Facultatis Scientiarum Naturalium Univsitatis Masarykianae Brunensis. 31-32, (2001-2002), Geology, Brno, 19-22.

ĆORIĆ, S. 2005a: Endemic Sarmatian and Pannonian calcareous nannoplankton from the Central Paratethys. - Abstracts, 12th RCMNS, Congress, Vienna, 53-54.

ĆORIĆ, S. 2005b: Endemical Pannonian calcareous nannoplankton: Genus Isolithus Luljewa, 1989 in the Central Paratethys. - In: Jovanović, G., Rundić, Lu., Dulić, I., Knežević, S., Simić, V., Kovačev, N., KnežEvić, S. \& Jovanović, D. (eds): 1st International Workshop: Neogene of Central and Southeastern Europe, Fruška Gora Mt., 10-11.

Ć́orić, S., KovaČíc, M., Bortek, Ž., Marković, F. \& VRSALJKo, D. 2017: Changes in Middle/Upper Miocene calcareous nannoplankton assemblages (Central Paratethys; Našice; Croatia) - paleoecology and stratigraphy. $-7^{\text {th }}$ International Workshop Neogene of Central and South-Eastern Europe, 28-31.5., Abstratcts Book, Velika, 20-21.

DeflandRE, G. 1947: Braarudosphaera nov. gen., type d'une famille nouvelle de Coccolithophorides actuels a elements composites. Comptes Rendus Hebdomadaires des Séances de l'Académie des Sciences, Paris 225, 439-441. 
Deflandre, G. 1953: Hétérogénéité intrinsèque et pluralité des éleménts dans les coccolithes actuels et fossiles. - Comptes Rendus Hebdomadaires des Séances de l'Académie des Sciences, Paris 237, 1785-1787.

Deflandre, G. \& FERT, C. 1954: Observations sur les coccolithophoridés actuels et fossiles en microscopie ordinaire et électronique. Annales de Paléontologie. 40, 115-176.

Fornaciari, E., Di Stefano, A., Rio, D. \& Negri, A. 1996: Middle Miocene quantitative calcareous nannofossil biostratigraphy in the Mediterranean region. - Micropaleontology 42, 37-63. https://doi.org/10.2307/1485982

GALOVIĆ, I. 2017: Sarmatian calcareous nannofossil assemblages in the SW Paratethyan marginal marine environments: Implications for palaeoceanography and the palaeoclimate. - Progress in Oceanography 156, 209-220, http://dx.doi.org/10.1016/j.pocean.2017.05.011

Galović, I. \& Young, J. 2012: Revised taxonomy of some Middle Miocene calcareous nannofossils in the Paratethys. - Micropaleonto$\operatorname{logy} \mathbf{5 8 / 4 , 3 0 5 - 3 3 4 . ~}$

GARDET, M. 1955: Contribution à l'étude des coccolithes des terrains néogènes de l'Algérie. - Publications du Service de la Carte Géologique de l'Algérie (Nouvelle Série) 5, 477-550.

GARTNER, S. 1967: Calcareous nannofossils from Neogene of Trinidad, Jamaica, and Gulf of Mexico. - University of Kansas Paleontological Contributions, Papers 29, 1-7.

GARTNER, S. 1969: Correlation of Neogene planktonic foraminifera and calcareous nannofossil zones. - Transactions of the Gulf-Coast Association of Geological Societies 19, 585-599.

GRAN, H. H. \& BRAARUD, T. 1935: A quantitative study of the phytoplankton in the Bay of Fundy and the Gulf of Maine (including observations on hydrography, chemistry and turbidity). - Journal of the Biological Board of Canada 1, 279-467.

HAJós, M. 1985: Diatomeen des Pannonien in Ungarn. - In: PAPP, A (ed.): M6 Pannonien (Slavonien und Serbien). - Chronostratigraphie und Neostratotypen, Miozän der Zentralen Paratethys, 8, 534-585.

HAQ, B. U. \& BERGGREN, W. A. 1978: Late Neogene calcareous plankton biochronology of the Rio Grande Rise (South Atlantic Ocean). Journal of Paleontology 52, 1167-1194.

Harzhauser, M. \& Piller, W. E. 2007: Benchmark data of a changing sea - Paleogeography, Paleobiogeography and events in the Central Paratethys during the Miocene. - Palaeogeography, Palaeoclimatology, Palaeoecology 253, 8-31.

Hay, W. W., Mohler, H. P., Roth, P. H., Schmidt, R. R. \& BoudreauX, J. E. 1967: Calcareous nannoplankton zonation of the Cenozoic of the Gulf Coast and Caribbean-Antillean area, and transoceanic correlation. - Transactions of the Gulf-Coast Association of Geological Societies 17, 428-480.

JERKović, L. 1970: Noëlaerhabdus nov. gen. type d'une nouvelle familia de Coccolithophoridés fossils: Noëlaerhabdaceae du miocène de Yugoslavie. - Comptes Rendus Hebdomadaires des Séances de l'Académie des Sciences, Paris, Série D - Sciences Naturelles. 270, 468-470.

JERKOVIĆ, L. 1971: Noelaerhabdus bekei nov. sp. des Coccolithophorides du pannonien de Belgrade. - Bulletin Scientifique, Yougoslavie. A 16, 207-207.

KAMPTNER, E. 1931: Nannoconus steinmanni novo gen., novo spec., ein merkwurdiges gesteinbildendes Mikrofossil aus dem jungeren Mesozoikum der Alpen. - Paläontologische Zeitschrift 13, 288-298.

Kováč, M., Fordinál, K., Grigorovich, A. S. A., Halásová, E., HudáčKová, N., Joniak, P., Pipík, R., SAbol, M., Kováčová, M. \& SLIVA, L. 2005: Západokarpatské fosílne ekosystémy a ich vztah k paleoprostrediu v kontexte neogénneho vývoja euroázijského kontinentu. - Geologické práce, Správy, ŠGÚDŠ 111, 61-121.

Kováč, M., Andrejeva-Grigorovič, A., BarÁth, I., BeláčKovÁ, K., FordinÁl, K., HalásovÁ, E., Hók, J., HudáčKová, N., Chalupová, B., KováčovÁ, M., PIPÍK, R., SLIVA, L. \& ŠUJAN, M. 2008: Litologické, sedimentologické a biostratigrafické vyhodnotenie vrtu ŠVM1 Tajná. - Geologické práce, Správy ŠGUDŠ 114, 51-84.

LoEblich, A. R. \& TAPPAN, H. 1978: The coccolithophorid genus Calcidiscus Kamptner and its synonyms. - Journal of Paleontology, 52, 1390-1392.

LyUl'EVA, S. A. 1989: New Miocene and Pliocene calcareous nannofossils of the Ukraine. - Dopovidi Akademii Nauk Ukrains 'koi RSR Seriya B: Geologichni, Khimichni ta Biologichni Nauki 1, 10-14.

Manconi, R. \& Pronzato, R. 2015: Chapter 8 Phylum Porifera. - In: Thorp, J. \& Rogers, D. C. (eds): Thorp and Covich's Freshwater Invertebrates, Vol. I: Ecology and General Biology. - 4th Edition, Elsevier, London 133-157. https://doi.org/10.1016/C2010-0-65590-8

Manconi, R. \& Pronzato, R. 2016: How to survive and persist in temporary freshwater? Adaptive traits of sponges (Porifera, Spongillida). A review. - Hydrobiologia 782, 11-22. https://doi.org/10.1007/s10750-016-2714-x

Martini, E. \& Bramlette, M. N. 1963: Calcareous nannoplankton from the experimental Mohole drilling. - Journal of Paleontology 37/4, 845-855.

MĂRUNȚEANU, M. 1995: Noelaerhabdus bonagali n. sp. (calcareous nannoplankton) in the Upper Malvensin - Romanian Banat. - Romanian Journal of Paleontology 76, 99-101.

MĂRUNȚEANu, M. 1996: Pannonian calcareous nannoplankton. - Anuarul Institutului de Geologie sii Geofizică, Annuaire de l'Institut de Geologie et de Geophysique 69/1, 125-129.

MĂRunȚEANu, M. 1997: Evolution line of the endemic genus Noelaerhabdus (Pannonian; Pannonian Basin). - Acta Palaeontologica Romaniae 1, 96-100.

MăRunțEAnU, M., ŞERBAn, E. \& Rusu, A. 1994: Neogene of Caransebeş-Mehadia Basin. - Romanian Journal of Stratigraphy 76, $79-87$.

MARTINI, E. 1971: Standard Tertiary and Quaternary calcareous nannoplankton zonation. - Proceedings of the II Planktonic Conference. Ed. Tecnoscienza, Roma, 739-785.

MinaJlović, D. 1993: Praenoelaerhabdus, a new endemic genus of calcareous nannoplankton from the Pannonian Basin. - Geologica Carpathica, 44/1, 59-62. 
MurRay, G. \& Blackman, V. H. 1898: On the nature of the Coccospheres and Rhabdospheres. - Philosophical Transactions of the Royal Society of London B: Biological Sciences 190/1, 427-441.

OKAdA, H. \& McInTYRe, A. 1979: Seasonal distribution of the modern Coccolithophores in the western North Atlantic Ocean. - Marine Biology 54, 319-328. https://doi.org/10.1007/bf00395438

Perch-Nielsen, K. 1968: Der Feinbau und die Klassifikation der Coccolithen aus dem Maastrichtien von Danemark. - Biologiske Skrifter, Kongelige Danske Videnskabernes Selskab 16, 1-96.

Perch-Nielsen, K. 1985: Cenozoic calcareous nannofossils, - In: Bolli, H. M., SAunders, J. B. \& Perch-Nielsen, K. (eds): Plankton stratigraphy. Cambridge University Press, 427-554. https://doi.org/10.1002/gj.3350250216

Piller, W. E., Harzhauser, M. \& Mandic, O. 2007: Miocene Central Paratethys stratigraphy - current status and future directions. Stratigraphy 4, 151-168.

RAHMAN, A. \& Roth, P. H. 1990: Late Neogene paleoceanography and paleoclimatology of the Gulf of Aden region based on calcareous nannofossils. - Paleoceanography 5, 91-107. https://doi.org/10.1029/PA005i001p00091

Raffi, I., Backman, J., Fornaciari, E., Pälike, H., Rio, D., Lourens, L. J. \& Hilgen, F. J. 2006: A review of calcareous nannofossil astrobiochronology encompassing the past 25 million years. - Quaternary Science Reviews 25, 3113-3137. https://doi.org/10.1016/ j.quascirev.2006.07.007

RöGL, F. 1998: Palaeogeographic Considerations for Mediterranean and Paratethys Seaways (Oligocene to Miocene). - Annalen des Naturhistorischen Museums in Wien 99A, 279-310.

RöGL, F. 1999: Mediterranean and Paratethys. Facts and Hypotheses of an Oligocene to Miocene Paleogeography (Short Overview). Geologica Carpathica 50,339-349.

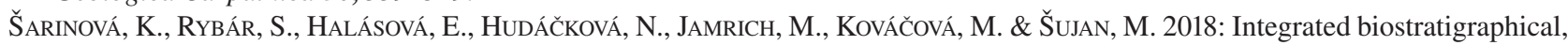
sedimentological and provenance analyses with implications lithostratigraphic ranking: the Miocene Komjatice Depression of the Danube Basin. - Geologica Carpathica 69/4, 382-409. https://doi.org/10.1515/geoca-2018-0023

SCHILler, J. 1930: Coccolithineae. - In: RABEnHORSt, L. (ed.) Kryptogamen-Flora von Deutschland, Österreich und der Schweiz. Akademische Verlagsgesellschaft, Leipzig, 89-267.

Sebe, K., Konrád, Gy. \& Sztanó, O. 2021: An exceptional surface occurrence: the middle to upper Miocene succession of PécsDanitzpuszta (SW Hungary). - Földtani Közlöny 151/3, 235-252.

Silva, A., Palma, S., Oliveira, P. B. \& Moita, M. T. 2009: Calcidiscus quadriperforatus and Calcidiscus leptoporus as oceanographic tracers in Lisbon Bay (Portugal). - Estuarin, Coastal and Shelf Science 81, 333-344. https://doi.org/10.1016/j.ecss.2008.11.010

Steininger, F. F. \& Wessely, G. 2000: From the Tethyan Ocean to the Paratethys Sea: Oligocene to Neogene Stratigraphy, Paleogeography and Paleobiogeography of the circum-Mediterranean region and the Oligocene to Neogene Basin evolution in Austria. - Mitteilungen der Österreichischen Geologischen Gesellschaft 92, 95-116.

STRADNER, H. 1960: Über Nannoplankton-Invasionen im Sarmat des Wiener Beckens. - Erdoel Zeitschrift für Bohr- und Fördertechnik Gewinnung - Aufbereitung - Transport 76/12, 430-432.

Stradner, H. 1963: New contributions to Mesozoic stratigraphy by means of nannofossils. - Proceedings of the Sixth World Petroleum Congress, Section 1 Paper 4, 167-183.

Szuromi-Korecz, A., Magyar, I., Sztanó, O., Csoma, V., Botka, D., Sebe, K., Tóth, E. 2021: Various marginal marine environments in the Central Paratethys: Late Badenian and Sarmatian (middle Miocene) marine and non-marine microfossils from PécsDanitzpuszta, southern Hungary. - Földtani Közlöny 151/3, 275-304.

THEODORIDIS, S. 1984: Calcareous nannofossil biostratigraphy of the Miocene and revision of the helicoliths and discoasters. - Utrecht Micropaleontological Bulletin 32, 1-271.

TraXLER, L. 1894: Ephydatia fossilis, eine neue Art der fossilen Spongilliden. - Földtani Közlöny 24, $234-237$.

VAROL, O. \& Houghton, S. 1996: A review and classification of fossil didemnid ascidian spicules. - Journal of Micropalaeontology 15, 135-149.

WALLICH, G. C. 1877: Observations on the coccosphere. - Annals and Magazine of Natural History 19, 342-350.

WinTER, A. \& Siesser, W. G. 1994: Coccolithophores. - Cambridge University Press, Cambridge, 242 p.

WISE, S. W. 1983: Mesozoic and Cenozoic calcareous nannofossils recovered by DSDP Leg 71 in the Falkland Plateau region, Southwest Atlantic Ocean. - Initial Reports of the Deep Sea Drilling Project 71, 481-550.

YounG, J. R. \& Bown, P. R. 1997: Cenozoic calcareous nannoplankton classification. - Journal of Nannoplankton Research 19/1, 36-47.

Young, J. R., Geisen, M., Cros, L., Kleijne, A., Probert, I. \& OstergaArd, J. B. 2003: A guide to extant coccolithophore taxonomy. Journal of Nannoplankton Research, Special Issue. 1, 1-132.

Manuscript received:22/02/2021 